PDFlib PLOP: PDF Linearization, Optimization, Protection

Page inserted by evaluation version www.pdflib.com - sales@pdflib.com 


\title{
Relationship between Membrane Depolarization and Intracellular Free Calcium in Individual Nerve Terminals from the Neurohypophysis
}

\author{
EDWARD L. STUENKEL \\ Department of Physiology \\ University of Michigan \\ Ann Arbor, Michigan 48109-0622
}

The release of transmitter/hormone from nerve terminals is dependent on depolarization-induced changes in intraterminal free $\left[\mathrm{Ca}^{2+}\right]$, yet anatomical limitations of vertebrate nerve endings have largely precluded direct monitoring of such changes at single axon endings. As a result the quantitative relationship of the change in $\left[\mathrm{Ca}^{2+}\right]_{i}$ to exocytosis in vertebrate endings remains virtually uncharacterized. Using axon terminals isolated from the neurohypophysis of the rat, changes in $\left[\mathrm{Ca}^{2+}\right]_{i}$ in individual endings in response to depolarizing stimuli were directly quantitated by dual wavelength microspectrofluorometry of cytoplasmic fura-2. The mean basal $\left[\mathrm{Ca}^{2+}\right]_{i}$ was $66 \pm 4 \mathrm{nM}(\mathrm{n}=212, \pm \mathrm{SEM})$, a value similar to most excitable and nonexcitable cells. Membrane depolarization evoked by elevation of extracellular $\left[\mathrm{K}^{+}\right]$resulted in a rapid, dose-dependent increase in $\left[\mathrm{Ca}^{2+}\right]_{i}$ that was not present in medium lacking extracellular $\mathrm{Ca}^{2+}$ (no added $\mathrm{Ca}^{2+}$ plus $1 \mathrm{mM}$ EGTA) and was greatly reduced by the inorganic $\mathrm{Ca}^{2+}$ channel blockers $\mathrm{Cd}^{2+}$ and $\mathrm{La}^{3+}$. Application of the dihydropyridine nicardipine dose dependently reduced the rise in $\left[\mathrm{Ca}^{2+}\right]_{i}$ evoked by $50 \mathrm{mM} \mathrm{K}^{+}(93 \%$ block at $10 \mu \mathrm{M})$ as did desmethoxyverapamil (D888). These results suggest that the evoked rise in $\left[\mathrm{Ca}^{2+}\right]$ is mediated by an L-type $\mathrm{Ca}^{2+}$ channel under these depolarizing conditions. Recovery of basal $\left[\mathrm{Ca}^{2+}\right]_{i}$ on removal of elevated $\mathrm{K}^{+}$showed an initial rapid decline followed by a slower phase.

Initial studies have found the change in $\left[\mathrm{Ca}^{2+}\right]_{i}$ in single nerve endings, in response to given $\mathrm{K}^{+}$-induced depolarizations, to closely correlate to vasopressin release monitored from populations of isolated endings. ${ }^{1}$ The close correlation suggests that $\mathrm{Ca}^{2+}$ influx by way of the L-type $\mathrm{Ca}^{2+}$ channel is associated with release under these depolarizing conditions. A strengthening of this conclusion was provided by the close relationship between dihydropyridine block of secretion $\left(\mathrm{IC}_{50}=4 \mu \mathrm{M}\right)$ with the observed block of $\mathrm{Ca}^{2+}$ influx and rise in $\left[\mathrm{Ca}^{2+}\right]_{\mathrm{i}}$ (approx. $\mathrm{IC}_{50}=2 \mu \mathrm{M}$ ). Furthermore, there is a close relationship between the kinetics of a change in $\left[\mathrm{Ca}^{2+}\right]_{i}$ and that of vasopressin release in the present study when challenged with a 30 -s pulse of $50 \mathrm{mM}^{+}$[arginine vasopressin release graciously performed by Dr. J. J. Nordmann]. For depolarizations longer than $30 \mathrm{sec}$, however, $\left[\mathrm{Ca}^{2+}\right]_{\mathrm{i}}$ remained elevated, although release rapidly declined. Thus, the phasic nature of the vasopressin secretory response is not limited by inactivation of $\mathrm{Ca}^{2+}$ entry.

Vasopressin release from the neurohypophysis has been reported to be directly influenced at the level of the nerve endings by a variety of bioactive peptides. These include dynorphin ${ }^{2}$ and cholecystokinin, ${ }^{3}$ which are believed to be autoregulatory, and by the peptide hormone relaxin. ${ }^{4}$ None of these peptides were found to affect either the basal $\left[\mathrm{Ca}^{2+}\right]_{i}$ value or to alter the change in $\left[\mathrm{Ca}^{2+}\right]_{i}$ evoked by either $25 \mathrm{mM}$ 
or $50 \mathrm{mM}$ extracellular $\mathrm{K}^{+}$. By contrast, the opioid receptor agonist, U50488 (a selective kappa agonist), did significantly reduce the evoked rise in $\left[\mathrm{Ca}^{2+}\right]_{i}$ to $\mathrm{K}^{+}$ depolarization without affecting the basal value.

\section{REFERENCES}

1. Cazalis, M., G. Dayanithi \& J. J. Nordmann. 1987. Hormone release from isolated nerve endings of the rat neurohypophysis. J. Physiol. (Lond.) 390: 55-70.

2. ZhaO, B. G., C. Chapman \& R. J. BiCKNELL. 1988. Functional kappa-opioid receptors on oxytocin and vasopressin nerve terminals isolated from the rat neurohypophysis. Brain Res. 462: 62-66.

3. Bondy, C. A., R. T. Jensen, L. S. Brady \& H. Gainer. 1989. Cholecystokinin evokes secretion of oxytocin and vasopressin from rat neural lobe independent of external calcium. Proc. Natl. Acad. Sci. USA 86: 5198-5201.

4. Dayanithi, G., M. Cazalis \& J. J. Nordmann. 1987. Relaxin affects the release of oxytocin and vasopressin from the neurohypophysis. Nature 325: 813-816. 